\title{
PEMANFAATAN BALE BANJAR SEBAGAI RUANG KREATIVITAS ANAK MUDA DI KOTA DENPASAR
}

\author{
Anak Agung Ngurah Anom Sanjaya, I Nyoman Harry Juliarthana \\ Program Studi Perencanaan Wilayah dan Kota, Fakultas Teknik, Universitas Hindu Indonesia \\ wahanomsanjaya@gmail.com \\ harryjuliarthana@gmail.com
}

\begin{abstract}
Ruang publik merupakan salah satu ruang yang bisa dimanfaatkan sebagai wadah aktivitas kreatif warga kota. Landry, (1995) berpendapat bahwa ruang publik dapat menjadi salah satu tempat mengakomodasi kreativitas. Kota Denpasar dengan pemanfaatan ruang yang cukup beragam sejatinya banyak memiliki ruang-ruang publik yang belum terpikirkan dan dapat dimanfaatkan fungsinya sebagai wadah aktivitas kreatif warga kotannya. Bale banjar merupakan salah satu ruang publik yang dimiliki di Kota Denpasar selain ruang publik berupa ruang terbuka hijau yang dapat dimanfaatan sebagai wadah aktivitas kreatif warga Kota Denpasar khususnya anak-anak muda. Dilihat dari fenomena yang sudah dijabarkan sebelumnya, tujuan penelitian ini untuk mengidentifikasi lebih mendalam mengenai sejauh mana ruang di bale banjar bisa dimanfaatkan sebagai ruang kreativitas dan apa saja bentuk kreativitas yang dapat ditampung di bale banjar serta bagaimana arah pengembangan pemanfaatan ruang di bale banjar sebagai ruang kreatif anak-anak muda di Kota Denpasar, dan nantinya dapat dilihat juga sejauh mana peranan Banjar sebagai ruang kreativitas dalam menunjang Kota Kreatif di Kota Denpasar. Cakupan amatan penelitian ini nantinya akan difokuskan di beberapa titiktitik kawasaan yang mencakupi beberapa bale banjar yang mengalami fenomena pemanfaatan fungsi ruang banjar sebagai ruang kreativitas sesuai dengan spasial tata guna lahan di Kota Denpasar.

Penelitian ini menggunakan metode deskriptif kualitatif dan metode delphi, dengan mengambil beberapa titik-titik bale banjar yang mencakupi beberapa kawasan berdsarkan spasial tata guna lahan di Kota Denpasar. Teknik analisis deskriptif kualitatif dan analisis metode delphi dimana pada prinsipnya metode delphi merupakan teknik peramalan intuitif yang digunakan untuk mencapai suatu konsesus dari suatu kelompok ahli (expert). Berdasarkan hasil penelitian ditemukan bahwa (1), Dari 9 (sembilan) titik bale banjar yang diteliti menunjukan bahwa keberagaman aktivitas /kegiatan kreatif anak muda sangat beragam hal ini dikarenekan oleh pemanfaatan lahan dan pengaruh aktivitas dilingkungan sekitar kawasan bale banjar, seperti ; Bale banjar di kawasan permukiman, Bale banjar di Kawasan Pariwisata, Bale banjar di Kawasan Perdagangan Jasa dan Pemerintahan /Perkantoran. (2), Wantilan dan natah merupakan ruang-ruang yang lebih sering dimanfaatkan sebagai wadah kreativitas anak-anak muda. (3), Bale banjar sangat berperan sebagai wadah aktivitas kreatif anak-anak muda di Kota Denpasar. Dilihat dari banyaknya aktivitas dan proses kreatifitas yang dapat ditampung didalam ruang bale banjar berupa aktivitas-aktivitas kreatif menunjukkan bahwa bale banjar mewadahi dan menyedikan ruang-ruang aktivitas kreatif anak-anak muda di Kota Denpasar
\end{abstract}

KATA KUNCI : Bale banjar, ruang kreativitas dan anak-anak muda

\section{Pendahuluan}

Pada umumnya ruang publik merupakan suatu wadah/tempat yang dapat diakses oleh masyarakat dan digunakan untuk berkegiatan, berkumpul serta berinteraksi antar masyarakat. Caar (1992) dalam Sawitri, 2017 menjelaskan bahwa ruang publik merupakan ruang atau lahan umum tempat masyarakat dapat melakukan kegiatan fungsional maupun kegiatan sampingan lainnya yang dapat mengikat komunitas, baik kegiatan sehari-hari maupun berkala. Hal ini menunjukkan bahwa ketersediaan ruang berupa ruang publik sebagai wadah aktivitas kreatif warga kotanya merupakan hal yang sangat penting. Berbicara mengenai ruang publik di sebuah kota khususnya Kota Denpasar sejatinya masih banyak memiliki ruang-ruang publik yang belum terpikirkan dan dapat dimanfaatkan fungsinya sebagai wadah aktivitas kreatif warga kotannya. Seperti median jalan, pedestrian, sempadan sungai, bale banjar, kampus, dan masih banyak ruangruang lainnya. Dimana ruang-ruang tersebut sejatinya bisa dimanfaatkan fungsinya sebagai ruang-ruang aktivitas kreatif warga kota.

Kota Denpasar memiliki potensi ruang lainnya yang dapat dioptimalkan pemanfaatannya sebagai ruang publik untuk mewadhi aktivitas kreatif warga kota, berupa Bale Banjar. Bale Banjar merupakan salah satu ruang publik, selain ruang publik dalam bentuk ruang terbuka yang dimiliki Bali khususnya Kota Denpasar. Bale Banjar merupakan wadah yang digunakan oleh warga banjarnya untuk melaksanakan kegiatankegiatan/aktivitas sehari-sehari yang biasa kerama banjar (warga banjar) lakukan di dalamnya. Bale banjar merupakan sebuah bangunan komunal tempat berkumpul dengan jangkauan kawasan yang tersebar di setiap Desa Pakraman/Adat di Bali. Dari total luas daratan yang mencapi 12.778 Ha, Kota Denpasar memiliki 357 (tiga ratus lima puluh tujuh) titik bale banjar yang tersebar di seluruh wilayah Kota Denpasar (Peraturan Daerah No. 27 Tahun 2011).

Pemanfaatan bangunan banjar berupa Bale banjar sebagai wadah untuk beraktivitas terlihat 
sejak dahulu, dimana keberadaan bale banjar saat itu difungsikan sebagai pusat-pusat (sentral) kegiatan oleh warga banjarnya. Hampir seluruh warga (krama) banjar senang melakukan akifitasaktivitas di bale banjar, dimulai dari mengobrol, tempat bermain anak-anak, magecel ayam, menjemur gabah, mempersiapkan sarana dan prasarana upacara (keagamaan dan adat), serta aktivitas-aktivitas lainnya yang krama banjar (warga banjar) lakukan setelah istirahat dari perkejaannya di sawah.

Pemanfaatan bale banjar sebagai ruang aktivitas juga dilakukan oleh warga banjar lainnya terutama anak-anak muda. Anak-anak muda banjar (Sekaa Teruna Teruni) biasanya lebih dominan dalam memanfaatkan ruang banjarnya sebagai ruang aktivitas serta ruang kreativitasnya. Bentuk pemanfaatanya-pun lebih berpariasi. Diluar fungsi utama bale banjar yang digunakan sebagai ruang untuk menyamakan visi dengan cara rapat (sangkep), banyak aktivitas-aktivitas lainnya yang mereka biasa lakukan di banjar, dimulai dari berdiskusi, berkolaborasi, olahraga, melakukan aktivitas-aktivitas budaya (seperti membuat ogohogoh, layang-layang, latihan megambel, menari, musik dan sejenisnya).

Dilihat dari dinamika aktivitas di bale banjar yang sudah dijabarkan sebelumnya, pemanfaatan bale banjar yang sejatinya memiliki potensi sebagai wadah aktivitas kreatif warganya sangat memungkinkan untuk terealisaisi. Bale banjar yang memiliki posisi sangat strategis untuk mewadahi aktivitas-aktivitas warganya, semenjak itu sudah dimanfaatkan sebagai sentral kegiatan/aktivitas warga banjarnya. Ketika dilihat dari bentuk ruang serta jangkauan masyarakat dalam mengakses ruang bale banjar, sejatinya bale banjar bisa dioptimalkan dalam pemanfaatan fungsinya sebagai wadah aktivitas kreatif bagi warga banjar terutama anak-anak muda banjarnya. Namun, situasi tersebut tidak serta merta memberikan kebebasan dalam memanfaatkan ruang bale banjar sebagai wadah kreativitas anak-anak muda di Kota Denpasar. Perlu adanya penelitian lebih lanjut mengenai tata krama, norma-norma serta nilai-nilai yang harus dijaga bersama-sama mengingat di dalam ruang banjar tersebut ada beberapa zonazona/ruang yang tidak sembarang warga banjar bisa memanfaatkannya untuk melakukan aktivitasaktivitas kreatifnya. Dilihat dari fenomena yang sudah dijabarkan sebelumnya, adapun identifikasi yang perlu dilakukan mengenai aktivitas-aktivitas kreatif yang dapat ditampung didalam Bale Banjar dan sejauh mana peranan Bale Banjar sebagai ruang kreativitas dalam menunjang Kota Kreatif di Kota Denpasar.

\section{Metode Penelitian}

Dalam penelitian ini pendekatan yang dilakukan adalah melalui pendekatan kualitatif. digunakannya metode ini karena aspek yang akan dikaji brsifat kualitatif serta penekanan analisinya pada ketajaman dan kepekaan berpikir analisis dalam mengkaji suatu yang berkaitan mengenai bentuk kreativitas serta aktivitas anak-anak muda dalam memanfaatkan Bale Banjar sebagai ruang kreatif di Kota Denpasar, sehingga kepekaan terhadap kondisi dilapangan dengan cara observasi langsung dilapangan, mewawancaarai narasumbernarasumber berkompeten serta ketajaman dalam pengamatan dilapangan sangat ditekannkan demi mendapatkan jawaban mengenai mengenai aktivitas-aktivitas kreatif yang dapat ditampung didalam Bale Banjar dan sejauh mana peranan Bale Banjar sebagai ruang kreativitas dalam menunjang Kota Kreatif di Kota Denpasar

\section{Hasil Penelitian dan Pembahasan}

Wilayah Kota Denpasar memiliki luas daratan $12.778 \mathrm{Ha}$, yang terletak pada koordinat $08^{0} 36^{\prime} 20^{\prime \prime}$ - 08 $48^{\circ} 48^{\prime \prime}$ LS dan $115^{\circ} 10^{\prime} 00^{\prime \prime}$ $115^{0} 16$ '26" BT. Secara administrasi, Kota Denpasar terbagi menjadi 4 wilayah kecamatan, 27 Desa dan 16 Kelurahan. Batas-batas wilayah Kota Denpasar terdiri dari :

Sebelah Utara : Kecamatan Mengwi dan Kecamatan Abiansemal Kabupaten Badung;

Sebelah Timur : Selat Badung, Kecamatan Sukawati, Kabupaten Gianyar;

Sebelah Selatan: Selat Badung, Teluk Benoa dan Kecamatan Kuta, Kabupaten Badung; dan

Sebelah Barat : Kecamatan Kuta dan Kecamatan Kuta Utara Kabupaten Badung.

\section{Karateristik Lokasi Penelitian}

Ruang wilayah Kota Denpasar terdiri atas total palemahan 35 (tiga puluh lima) Desa Pakraman dan 357 (tiga ratus lima puluh tujuh) Bale banjar yang tersebar di wilayah Kota Denpasar. Dari jumlah total Bale banjar yang tersebar di setiap Desa Pakraman di Kota Denpasar hanya beberapa titik Bale banjar saja yang digunakan sebagai lokasi/fokus dalam penelitian ini. Penelitian ini akan difokuskan di beberapa titik-titik kawasaan yang mencakupi beberapa Bale banjar berdsarkan spasial tata guna lahan di Kota Denpasar.

- Kawasan Permukiman (Bale Banjar Kehen Kesiman, Bale Banjar Kesambi Kesiman, Bale Banjar Pande Pedungan)

- Kawasan Pariwisata (Bale Banjar Sindu Kaja Sanur, Bale Banjar Batujimbar Sanur, Bale Banjar Semawang Sanur)

- Kawasan Perdagangan Jasa dan Pemerintahan/Perkantoran (Bale Banjar Titih Denpasar, Bale Banjar Pagan Kaja Sumerta, Bale Banjar Pemeregan Denpasar) 


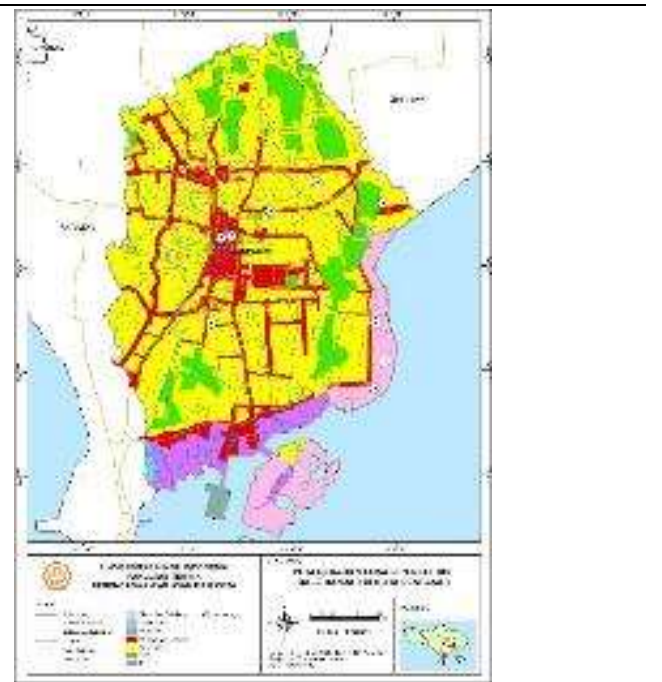

Gambar 1. Peta Sebaran Bale banjar di Kota Denpasar

Sumber: RTRW Kota Denpasar Tahun 2011-2031 diolah dan Observasi Peneliti 2018

Aktivitas-aktivitas kreatif yang dapat ditampung dimasing-masing Bale Banjar yang diteliti berdsarkan spasial tata guna lahan di Kota Denpasar.

Berbicara mengenai aktivitas-aktivitas kreatif di bale banjar, adapun aktivitas yang dapat dikatagorikan sebagai kegiatan/aktivitas kreatif dilihat dari ide dan proses pengerjaanya sehingga menghasilkan karya-karya kreatif. Seperti halnya kegiatan/aktivitas pembuatan layang- layang, ogoh-ogoh, latihan menari dan tabuh, bazzar dan serangkaian kegiatan HUT STT sejatinya merupakan aktivitas kreatif. Kreativitas ini dilihat dari konten/isi dari kegitan tersebut, misalnya kegiatan tersebut dapat menghadirkan dan mengandung seni musik, seni pertunjukan, kriya dan ada unsur kegiatan kreatif didalamnya maka kegiatan tersebut merupakan kegiatan/aktivitas kreatif. Ketika itu terpenuhi dalam sub sektor kreatif atau kreativitas yang dijabarkan (Howskin, 2002) maka kegiatan tersebut dapat dikatagorikan sebagai aktivitas kreatif.

a. Kawasan Permukiman, karakteristik aktivitas anak muda yang terwadahi dalam bentuk organisasi yang ada di lingkungan banjar berupa sekaa terunanya sebagian besar mewadahi aktivitas-aktivitas warga didalam kawasan permukiman seperti ; aktivitas budaya (menari dan tabuh), pembuatan ogohogoh/layang-layang dan festival/acara-acara yang dikemas sedemikian rupa dan dapat mewadahi aktivitas/potensi-potensi yang dimiliki oleh warga banjarnya terutama anakanak muda.

b. Kawasan Pariwisata, sebagian besar aktivitas/kegiatan anak anak mudanya secara tidak langsung mengakomodasi/mewadahi aktivitas-saktivitas di kawasan pariwisata. Dimana anak-anak muda di bale banjar tersebut lebih sering melakukan kegiatankegiatannya dalam bentuk festival-festival, seperti festival mini maupun festival yang bersekala besar. Biasanya festival yang digagas oleh anak-anak muda ini akan mewadahi potensi-potensi serta kreativitas yang dimiliki disetiap individu-individu di masing-masing bale banjar, seperti ; pagelaran seni (tabuh, tari dan seni pertunjukan), kuliner, dan aktivitas-aktivitas lainnya seperti pembuatan ogoh-ogoh/layanglayang dimana secara tidak langsung aktivitas ini dapat menarik parawisatawan yang berada di sekitar lokasi festival tersebut untuk ikut bergabung dan bersolidaritas menikmati pertunjukan yang ditampilkan.

c. Kawasan Perdagangan Jasa dan Pemerintahan/Perkantoran, memiliki aktivitas pemuda yang hampir sama dengan aktivitas anak muda yang berada dilingkungan permukiman, seperti ; aktivitas budaya (menari dan tabuh), pembuatan ogohogoh/layang-layang dan diskusi. Namun dalam bentuk mengakomodasi aktivitas perdagangan dan jasa, bale banjar yang ada di pusat-pusat aktivitas ini hanya memfasilitasinya dalam bentuk penyediaan ruang seperti adanya optimalisasi ruang bale banjar yang di tingkat menjadi 2 (dua) sampai 3 (tiga) lantai, dimana lantai bagian bawah bale banjar ini dimanfaatkan sebagai aktivitas perdagangan dan jasa berupa toko-toko dan kantor yang disewakan.

Peranan Bale Banjar sebagai ruang kreativitas dalam menunjang Kota Kreatif di Kota Denpasar a. Filosofi dan Sejarah Bale banjar

Bebicara mengenai Banjar sebagai wadah organisasi yang memiliki sekala lebih kecil dari Desa Pakraman dan dapat menghimpun seluruh masyarakat dalam kesatuan sosial yang ada di lingkungan Bale banjar, sejatinya memiliki dinamika perkembangan yang sangat dinamis. Perkembangan Banjar dan Bale Banjarnya yang sangat dinamis dimulai dari awal terbentuknya banjar sebagai kesatuan sosial dalam wilayah atau teritori yang sama pada abad ke 10-11 bersamaan dengan munculnya subak dan desa pakraman (Wayan Griya dalam Sawitri, 2017).

- I Wayan Griya, (Maestro Kebudayaan Bali) Bale banjar merupakan rumah bersama bagi warga banjarnya. Dimana didalam bangunan bale banjar terdapat bangunan-bangunan pembentuk seperti rumah masyarakat adat bali pada umumnya seperti, bale daja, bale delod, bale dangin, bale dauh, merajan/tempat suci dan paon/dapur. Sedangkan di bale banjar terdapat bangunan tambahan berupa bale wantilan yang digunakan sebagai wadah aktivitas bersama bagi warga masyarakat di 
bale banjar tersebut. Sedangkan bangunan bale kulkul merupakan bangunan tambahan lainnya sebagai bangunan pembentuk bale banjar yang difungsikan sebagai alat/media komunikasi untuk warga banjarnya.

Menurut pernyataan ahli, perkembangan dinamika masyarakat bali yang terwadahi dalam tatanan sosial berupa Banjar melalui 4 fase/tahapan, diantaranya ;

- (Tahap pertama) ; Dimana Banjar berbasi budaya agraris (Ekonomi Pertanian). Pada waktu banjar berbasis sebagai budaya agraris, mata pencaharian, basis perekonomian warganya, sosial masyarakat, serta susunan banjarnya mengikuti struktur budaya agraris. Salah satu cirinya di bale banjar terdapat bangunan Jineng (bangunan yang digunakan sebagai tempat untuk menyimpan hasil panen/padi). Dikarenakan berbasis budaya agraris pada saat itu juga banjar menganut sistem bagaimana mereka bekerja dan bagi hasil, hal ini diatur didalam sistem tersebut dan berdasarkan kesetaraan dan kebersamaan bagi seluruh warga banjarnya.

- (Tahap kedua) ; Banjar sebagai pusat perekonomian (Ekonomi Kerajinan). Pemanfaatan ruang yang ada ada dibale banjar difungsikan sebagai wadah untuk melakukan aktivitas perekonomian didalamnya. Bale banjar sebagai pusat perekonomian, banyak bale banjar yang dioptimalkan fungsinya ruangnya sebagai tempat-tempat perdagangan seperti banyaknya lahan banjar yang disewakan menjadi los dan toko. Hal ini dikarenakan evolusi pada tahapan ke dua dan ke tiga menjadi pusat perekonomian kerajinan dan jasa.

- (Tahap ketiga) ; Banjar sebagai pusat ekonomi kreatif (Ekonomi Jasa), ekonomi kreatif yang dimaksud berupa aktivitasaktiitas kreatif yang dimiliki oleh warga banjarnya dimana aktivitas kreatif ini nantinya akan terhimpun dan terwadahi dalam bale banjar serta manajemen pengelolaanya akan dikelola bersama melalui kesepakatan bersama oleh warga banjarnya. Dari hasil aktivitas-aktivitas kreatif berupa karya ini nantinya diharapkan dapat menghasilkan perputaran perekonomian di lingkungan bale banjar.

- (Tahap keempat) ; Banjar sebagai pusat industri 4.0/generasi digital (Ekonomi Digtal/Smart Community), Untuk tahapa ke empat dengan generasi 4.0 dan melenial ini banyak bale banjar yang sudah mengarah ke ekonomi digital atau yang di sebut smart banjar.
Perkembangan dinamika bale banjar yang terjadi dari abad ke-10 sampai saat ini, sangat sesuai pada konsep ruang tradisional bali yang mengacu pada konsep Tri Premana (desa/tempat, kala/waktu, patra/kondisi), dimana perkembangan ruang serta dinamika perkembangan sosial masyarakat akan menyesuaikan desa/tempat, kala/waktu, patra/kondisi yang terjadi saat ini tanpa harus meninggalkan filosofi dan fungsi awal bale banjar yang digunakan sebagai acaun oleh seluruh masyarakat yang masuk didalam sistem sosial kemasyarakatan yang ada di Banjar. (Wayan Griya, Maestro Kebudayaan Bali, Wawancara 2018).

- I Made Marlowe Makharadhwaja Bandem, (Akademisi dan Praktisi Kreatif)

"Banjar memiliki fungsi sebagai kebersatuan masyarakat desa baik dalam bidang kultural, religi, adat-istiadat dan seni budaya. Individu dari masing-masing masyarakat akan berbaur dan bergabung dengan individu-individu lainnya dan menjadi bagian dari masyarakat banjar itu sendiri. Otomatis ketika bale banjar menjadi ruang terbuka bagi masyarakat banjarnya maka warga banjar akan melakukan aktivitasnya di bale banjar sebagai pusat aktivitas warga banjarnya". (Marloe Bandem, Wawancara 2018).

\section{b. Ruang dan Aktivitas Kreatof di Bale Banjar}

- I Made Marlowe Makharadhwaja Bandem, (Akademisi dan Praktisi Kreatif)

Munculnya pemahaman ekonomi kreatif saat ini secara sederhana ekonomi kreatif merupakan aktivitas-aktivitas yang menyenangkan yang bersifat kreasi seni yang dapat menghasilkan. Selain itu kreativitas merupakan aktivitas yang bisa dilakukan secara monotais (dijadikan penghasilan). Bukan berarti dengan membuat ruko di bale banjar merupakan bentuk ekonomi kreatif (etalase dagang), namun ketika bale banjarnya bisa melakukan aktivitas kreatif sesuatu yang kemudian secara terus menerus melakukan penghasilan itu akan dikatagorikan sebagai ekonomi kratif

Saat ini yang menarik adalah pengembangan kreativitas apa yang dapat ditampung di dalam bale banjar. ketika bercerita kreativitas dalam seni budaya maka hampir di seluruh bale banjar memiliki kreatifits tersebut. Namun berbicara mengenai aktivitas kreatif saat ini mulai banyak bale banjar yang melakukan aktivitas kreatifnya, seperti bale banjar tainsiat dan gemeh yang terkenal akan aktivitas kreatifnya berupa karya seni ogohogoh yang masuk dalam kriya sebagai aktivitas kreatif. 
Diihat dari perkembangan aktivitas-aktivitas yang terwadahi di bale banjar itu sendiri, membuktikan bahwa aktivitas yang diwadahi di bale banjar sangatlah dinamis. Aktivitas tersebut akan mengikuti trand/arah perkembangan aktivitas baru yang berkembang di masyarakat tanpa harus menghilangkan semangat dan filosofi ruang dan fungsi bale banjar itu sendiri. Yang terpenting harus disadari bahwa bale banjar itu tetap digunakan sebagai tempat berkumpul anak muda, dimana ketika anak-anak muda berkumpul pasti akan timbul ideide/pemikiran dan aksi-aksi untuk merealisasikan ide-ide tersebut. (Marloe Bandem, Wawancara 2018).

\section{- Arief Budiman, (Praktisi Kreatif)}

Aktivitas/kegiatan yang rutin dilakukan oleh sekaa teruna berupa, kegiatan layang- layang, ogoh-ogoh, latihan menari dan tabuh, bazzar dan serangkaian kegiatan HUT STT sejatinya merupakan aktivitas kreatif. Kreativitas mengacu pada kontennya/isinya, misalnya kegiatan/aktivitas tersebut dapat menghadirkan seni musik, seni pertunjukan, kriya dan ada unsur kegiatan kreatif didalamnya maka kegiatan tersebut merupakan kegiatan/aktivitas kreatif. Ketika itu terpenuhi dalam sub sektor kreatif atau kreativitas yang dijabarkan howskin maka kegiatan tesebut juga dapat dikatagorikan sebagai aktivitas kreatif.

"Saat ini aktivitas kreatif menjadi primadona, walaupun sebelumnya aktivitasnya sudah dilakukan oleh bebrapa banjar. hanya saja saat ini perlu mendorong dan memfokuskan kearah itu, bahwa ekonomi kreatif tersebut dimensi dan cara kerjanya seperti yang sejatinya mereka sudah lakukan sebelumnya. Seperti memberi pemahaman bahwa kegiatankegiatan rutin yang mereka lakukan selama ini merupakan aktivitas kreatif dan perlu ada pengembangan lebih lanjut. Tahapan pengembangan aktivitas kreativitas selanjutnya berupa bagaiana kreativitas itu terbentu dan tercipta dimulai dari ; Ide (proses kreasi), Proses produksi (mewujudkan proses kreasi/ide dalam bentuk karya), Distribusi (mendistrbusikan hasil karya ke konsumen), Konsumsi (bagaimana hasil kreativitas itu dinikmati oleh konsumen), Konservasi/pelestarian (menjaga kelestarian dari proses kreativitas itu terjadi)". (Arief Budiman, Wawancara 2018)

\section{c. Rangkuman dari Ulasan Para Ahli}

Dilihat dari tahap-tahapan dinamika perkembangan bale banjar dari menetap pada abad ke 10-11, dengan basis dinamika perkembangan bale banjarnya sebagai budaya agraris, selanjutnya berbasis ekonomi kerajinan sampai ekonomi kreatif dan nanti akan mengarah pada ekonomi digital. Hal ini menunjukkan bahwa dinamika perkembangan sosial budaya masyarakat di bale banjar sangat dinamis. Hal ini dikarenakan konsep ruang tradisional masyarakat bali yang mengacu pada konsep Tri Premana desa/tempat, kala/waktu, patra/kondisi dimana perkembangan ruang/kebudayaan masyarakat di bale banjar akan menyesuakan pada kondisi sosial marsyarakat saat ini tanpa harus keluar dari filosofi dan konsep kebudayaan masyarakat/warga banjar.

Sejatinya bale banjar dan warga banjarnya responsip dengan perkembangan jaman saat ini atau bisa disebut menyesuaikan trand perkembangan sosial masyarakat saat ini. Budaya bali dikenal fleksibel dan lentur menyesuaikan dengan perkembangan jamannya, namun kebudayaan bali khusunya kebudayaan, adat dan istiadat yang ada di bale banjar tidak akan lepas dari sejarah, fungsi awalnya dan budaya yang disepakati di bale banjar.

Dinamika perkembangan sosial masyarakat khususnya anak-anak muda banjar yang lebih sering memanfaatkan ruang aktivitasnya sebagai ruang kreativitas di bale banjar. Bale banjar juga dimanfaatkan sebagai tempat berkumpul bagi anak-anak muda, dimana ketika anak-anak muda berkumpul pasti akan timbul ide-ide/pemikiran dan aksi-aksi untuk merealisasikan ide-ide tersebut. Proses dari awal terciptanya ide sampai merealisasikan ide dengan aksi-aksi dan menghasilkan sebuah karya. Proses inilah yang dapat dikatagorikan sebagai aktivitas/kegiatan kreatif. Proses seperti ini sering terjadi di kelompok anak-anak muda banjar dimana proses ini terwadahi di bale banjar.

Dari proses kreatif yang terakomodir di bale banjar berupa aktivitas-aktivitas kreatif menunjukkan bahwa bale banjar mewadahi dan menyedikan ruang-ruang aktivitas kreatif anakanak muda di Kota Denpasar. Ketika ruang aktivitas dan kreativitas anak muda dapat diwadahi di ruang-ruang bale banjar sebagai ruang kreativitasnya, maka konsep Kota Kreatif di Kota Denpasar dapat terealiassi karena aktivitasaktivitas kreatif anak-anak muda dapat terwadahi di lingkungan terkecil di masyarakat yaitu bale banjar.

\section{Kesimpulan}


Berdasarkan hasil pembahasan sebelumnya, maka dapat ditarik kesimpulan sebagai berikut :

- Kreatifitas dan aktivitas yang dapat ditampung di Bale banjar

Mengenai aktivitas anak muda di masingmasing bale banjar sesuai dengan lokasi penelitian mengambil di 9 (sembilan) bale banjar yang tersebar di Kota Denpasar menunjukan bahwa keberagaman aktivitas /kegiatan kreatif anak muda sangat beragam hal ini dikarenekan oleh pemanfaatan lahan dan pengaruh aktivitas dilingkungan sekitar kawasan bale banjar, seperti ; Bale banjar di kawasan permukiman, Bale banjar di Kawasan Pariwisata, Bale banjar di Kawasan Perdagangan Jasa dan Pemerintahan / Perkantoran.

Peranan Bale banjar sebagai ruang kreatifitas dalam menunjang Kota Kreatif di Kota Denpasar

Representasi bale banjar yang dapat dimanfaatkan sebagai ruang kreatif anak-anak muda banjar (STT) menunjukkan bahwa bale banjar sangat berperan sebagai wadah aktivitas kreatif anak-anak muda di Kota Denpasar. Dilihat dari banyaknya aktivitas dan proses kreatifitas yang dapat ditampung didalam ruang bale banjar berupa aktivitas-aktivitas kreatif menunjukkan bahwa bale banjar mewadahi dan menyedikan ruang-ruang aktivitas kreatif anakanak muda di Kota Denpasar. Ketika ruang aktivitas dan kreatifitas anak muda dapat diwadahi di ruang-ruang bale banjar sebagai ruang kreatifitasnya, maka realisasi konsep Kota Kreatif di Kota Denpasar dapat terealiassi karena ativitas-aktivitas kreatif anak-anak muda dapat terwadahi di lingkungan terkecil di masyarakat yaitu bale banjar.

\section{Saran}

Berdasarkan kesimpulan dan hasil analisis sebelumnya, maka saran yang dapat diberikan adalah sebagai berikut

\section{a. Bagi Pemerintah}

- Diharapkan nantinya dapat diarahkannya pengembangan potensi-potensi aktivitas kreatif anak-anak muda di Kota Denpasar dengan merancang konsep pengembangan kreativitas terpadu. Agar nantinya aktivitas yang tertampug di bale banjar dapat berkembang dan berkelanjutan.

- Konsep pengembangan kreativitas terpadu yang dimaksud dalam bentuk pelatihan-pelatihan, apresiasi, pendampingan sampai pengelolaan menejemen yang nantinya dapat dilakukan secara berkelanjutan untuk memancing minat yang dimiliki oleh anak-anak muda untuk berkreatifitas kembali.

- Pemeritah dapat membantu meningkatkan fasilitas-fasilitas pendukung dalam bentuk sarana-prasarana seperti wifi dan fasilitasfasilitas lainnya guna mensuport aktivitasaktivitas kreatif anak-anak muda (STT) di bale banjar.

\section{b. Bagi Generasi Muda}

- Berani berkreativitas dan berinofasi dalam bentuk karya-karya baru dan bisa dikembangkan untuk meningkatkan kreativitas dan aktivitas yang ada di lingkungan Bale Banjar.

- Mengoptimalkan ruang-ruang bale banjar sebagai ruang aktivitas kreatif bagi anak-anak muda di lingkungan bale banjar

- Perlu adanya peningkatan aktivitas kreatif yang berpotensi untuk dikembangkan kembali yang mencerminkan cirikhas daerah sesuai dengan kondisi masing-masing wilayah di bale banjar

- Selanjutnya ruang bale banjar dapat dimanfaatkan sebagai kreatif hub (pusat kreatifitas) bagi warga dan anak-anak muda banjar (STT) untuk menampung/mewadahi kreatifitas-kreatifitas yang dimiliki oleh masing-masing individu atau kelompok yang ada dilingkungan bale banjar.

\section{c. Bagi Fungsi Bale banjar}

- Fungsi utama bale banjar harus tetap dipertahankan. Dimana fungsi utama bale banjar yang digunakan sebagai rumah bersama dan pusat aktivitas warga banjar serta anakanak muda banjar

- Dimana ketika anak-anak muda berkumpul pasti akan timbul ide-ide/pemikiran dan aksiaksi untuk merealisasikan ide-ide tersebut.

- Fungsi terbatas, bale banjar dapat dimanfaatkan sebagai pusat aktivitas kreatif anak-anak muda

\section{d. Dunia Akademis}

Penelitian ini dapat dijadikan dasar bagi penelitian selanjutnya dalam proses pengembangan keilmuan pada bidang perencanaan wilayah dan kota.

\section{Daftar Pustaka}

Carr, Stephen et al. (1992). Public Spaces. (Cambridge: Cambridge University Press). 
Covarrubias, Miguel. (1972). Island of Bali. (Kuala Lumpur: Oxford University Press).

Darmawan, Edy. (2003). Teori dan Implementasi Perancangan Kota. (Semarang: Universitas Diponogoro).

Gantini, dkk. (2012). Guna dan Fungsi pada Arsitektur Bale Banjar Adat di Denpasar. Bali. Temu Ilmiah IPLBI.

Gantini, Christina. (2014). Arsitektur 'Bale Banjar' sebagai Representasi Arsitektur Pertahanan Masyarakat Denpasar di Bali. Seminar Nasional Arsitektr Pertahanan (ARSHAN) 2014.

Hakim, Rustman. (1987). Unsur Perancangan dalam Arsitektur Lansekap. Jakarta.

Howkins, John. 2002. The Creative Economy: How People Make Money from Ideas. London: Penguin Press.

Kao, Jhon. 1996. Jamming : The Art and Discipline in Business Creativity

Kiswandono, Istiawati, 2005. "Ruang Kreativitas": Gudang 1000.000 ide?. Makalah Seminar. Surabaya: HDII Jatim.

Landry, C. dan Bianchini, F. 1995. The Creative City. Bournes Green: Comedia.

Landry, C. 2006. The Art of City-Making. London: Earthscean.

Lawson, Bryan. 2003. Language of Space. Italy: Architectural Press.

Meganada, I Wayan. 1990. Pola Tata Ruang arsitektur Tradisional dalam Perumahan KPR-BTN di Bali. Tesis S2 Jurusan Teknik Arsitektur Institut Teknologi Bandung.

Manisyah, Miranti. 2009. Kota Kreatif (Creative City), Penelusuran terhadap Konsep Kota Kreatif melalui Pengamatan Studi Kasus. Universitas Indonesia

Munandar, S.C. Utami, 1999. Pengembangan Kreatifitas Anak Berbakat. Jakarta: PT. Penerbit Rineka Cipta.

Prabawa, S.M. (2016). Transformasi Kehadiran Bale Banjar : Studi Kasus Banjar Titih, Kota Denpasar. (Depok: Dapertemen Teknik Arsitektur. Universitas Indonesia).

Putra, I.G.M. (1998). Arsitektur Bale Banjar Modern Tradisional Bali. Laporan Penelitian dalam Pemeran Arsitektur Pesta Kesenian Bali. (Denpasar: Fakultas Teknik. Universitas Udayana).

Sawitri, Adnya. N.P. (2017). Tipologi Perkembangan Pemanfaatan Bale Banjar dan Faktor-Faktor yang Memengaruhnya. Studi Kasus: Kota Denpasar, Provinsi Bali. Seminar Nasional SPACE \#3. 2017.

Soethama, A.G. (2014). Bali Tikam Bali. Denpasar: Art Fundation.

Sudata, I Nengah. 2002. Persepsi Masyarakat Terhadap Sistem Nilai Ruang Terbuka Tradisional Di Kota Denpasar. Tesis S2
Program Pascasarjana Universitas Diponegoro.

Umbara, D.M. Bagus (2014). Perubahan Fungsi Ruang Terbua Hijau Tradisional Bali. (Studi Kasus : Desa Sanr Kauh Denpasar). Prodi. Perencanaan Wilayah dan Kota, Fak. Teknik, Universitas Hindu Indonesia.

Windhu, Oka.I.A. (1985). Bangunan Tradisional Bali Serta Fungsinya. Dapertemen Pendidikan dan Kebudayaan Dirjen Kebudayaan.

Widiastuti. 1996. Pola Perubahan Pempatan Agung Akibat Perkembangan Kota (Studi Kasus Pusat Kota-Kota di Bali). Denpasar: Udayana University.

\section{Peraturan}

Kota Denpasar. Tahun 2011. Peraturan Daerah Kota Denpasar Nomer 27 Tahun 2011, Tentang Rencana Tata Ruang Wilayah Kota Denpasar Tahun 2011-2031. Lembaran Daerah Kota Denpasar Tahun 2011 Nomer 27. Sekretaris Daerah. Denpasar 